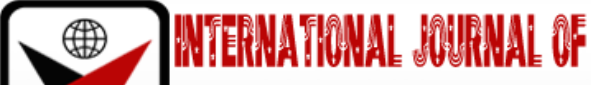

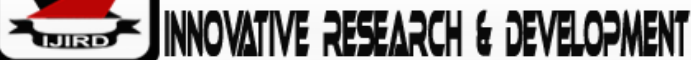

ISSN 2278-0211 (Online)

\section{Gregory Boyd Open Theistic Perspective: A Critical Analysis}

\author{
Orji Blessed Nyemobuchi \\ Doctoral Student, Department of Religious and Cultural Studies, \\ University of Port Harcourt, Rivers State, Nigeria \\ Dr. P.Z. Alawa \\ Senior Lecturer, Department of Philosophy, \\ University of Port Harcourt, Rivers State, Nigeria
}

\begin{abstract}
:
Gregory Boyd was a major proponent of open theism. He made outstanding and significant contributions to the openness model. Boyd was a pastor and claimed that his view of open theism does not contradict his vocation as a pastor. He rather maintains that the open view has practical theological relevance and agrees more with many Christian practices. The open view came to be known as a challenge to the traditional view of God. The traditional and classical notion of God presupposes a God who has exhaustive, complete and comprehensive knowledge of the future. God in the classical sense is all knowing. But open theism insists that God is omniscient but such omniscient knowledge does not include knowledge of the contingent future. For the open theists, divine foreknowledge is incompatible with human freewill. Boyd claims that he holds the notion of omniscience tenaciously but depending on the type of omniscience that is referred to. But do we have different types of omniscience? From the Biblical texts and from our practical and lived experiences, do we think that the open view is more a plausible model than the traditional view? Does the open view agree with Biblical texts? What is the philosophical implication of the open view? Does the open view actually unburden God with the problem of evil? If the future is open, can God be said to be in control? Gregory Boyd and E. Boyd enunciate their open view which we have analyzed in this study. But their view seems to contradict the basic perspective of the open modelanchored on the freedom of human action. This isdue to their position that God sometimes overrides the freedom of man to achieve his purpose. Also, their claim that they believe in Omniscience while they deny God's knowledge of the contingent future is implausible because to be omniscient is to know all things.
\end{abstract}

Keywords: Open theism, omniscience, freedom, determinism, Gregory Boyd, E. Boyd

\section{Introduction}

Gregory Boyd was a major proponent of open theism. He made outstanding and significant contributions to the openness model. Boyd was a pastor and claimed that his view of open theism does not contradict his vocation as a pastor. He rather maintains that the open view has practical theological relevance and agrees more with many Christian practices. The open view became known as a challenge to the traditional view of God. The traditional and classical notion of God presupposes a God who has exhaustive, complete and comprehensive knowledge of the future. That is, God is all knowing. But open theism insists that God is omniscient but not all knowing. For the open theists, divine foreknowledge is incompatible with human freewill. But Boyd does not see the open view as a challenge to the traditional view of God; for he claims that he holds the notion of omniscience tenaciously but depending on the type of omniscience that one is referring to. But do we have two or even more types of omniscience? Is Boyd right in his notion that he believes in omniscience but maintains that God and the future are open and can go in any direction? From the Biblical texts and from our practical and lived experiences, do we think that the open view is tenable? Does the open view remove the burden of the problem of evil from God? If the future is open, can God still be in control? In this study, we shall examine the above posers in the light of the view espoused by Gregory Boyd.

\subsection{Conceptual Clarification}

The main concept in our subject of discourse is open theism. Open theism is a movement that is making inroads into the domain of philosophy and theology. The open theism movement began in the twentieth century and it is a position that denies that God has comprehensive foreknowledge (Vanarragon, 2010). According to the open model, 'God can know only what can be known and that what humans will freely do in the future cannot be known before-hand; hence, God can never know infallibly, what will happen in any context involving human freedom (Basinger, 2003). This open view of God implies that the agent's long-term future is essentially unwritten and open. In the open theistic sense, for a being to be said to be omniscient it means that the being knows all truths and all true propositions. A thing could be said to be true if it conforms with reality. This is the corresponding theory of knowledge. For instance, if one says it is raining, then, there should be something in reality that corresponds to that assertion. That is, it should be raining. Or if one says that I am writing this 
article at this time, then, it should be the case that I am writing this article. This is why open theists argue that God does not have foreknowledge of contingent future because propositions of future contingents are not really true now. In other words, if one says that Blessed Orji would be president of Nigeria in 2023, that the statement is neither true nor false now. It is neither true nor false now because there is nothing in reality or in the world that makes it either true or false now. Also, free contingent actions can happen in any way as far as creatures have freewill. This is why the open theists contend that divine foreknowledge is incompatible with human freewill.

Open theism is opposed to the notion of middle knowledge proposed by Lius De Molina, the Spanish Jesuit Priest. Middle knowledge theory holds that God has knowledge of all actual states of affair, all metaphysical states of affairs, all possible states of affairs and what every creature would do in any situation it finds itself (Basinger 2003). Open theism rejects the last segment of middle knowledge theory which suggests that God knows what free creatures would do with their freedom. Its argument is that while we believe that God is omnipotent, we do know that God cannot make a square circle or make $1+1=3$ because it is impossible or illogical to do so. In the same vein, we can accept that God is omniscient but he lacks knowledge of the contingent future because such future is not true now.

This is the irony of the open model. Their argument is that they believe in omniscience but it depends on the type of omniscience referred to. If omniscience means that God knows all actual states of affairs, the open theists say they accept such a definition. Also, if omniscience is knowledge of what God has decreed to happen or of God's will and desires, they agree with that. But if the notion of omniscience is that God possesses knowledge of contingent future where creatures are free to choose, they do not accept that God has such foreknowledge. This open theistic view is in contradistinction to the idea of omniscience in the classical or traditional sense.Omniscience in the traditional model means that a being is capable of knowing all there is to know, including contingent future. Therefore, to know less is evidently with such a being. In other words, if anything is hidden from that being, including the free acts of men, then such a being cannot be a perfect being and cannot be God. But God as a perfect being is omniscient, hence, knows neither more nor less; for there is neither increase nor decrease in His knowledge.

According to Steve Brand (2003), omniscience is a state of being all knowing which theology ascribes to God. He further opines that God knows us intimately (Psalm 139:1-6, Matt.6:4,6.8) and such knowledge is cause for alarm for the unrighteous but for confidence for God's saints (Job 23:10, Ps. 34:15-16). In the view of Norman Kretzmann (1974) a perfect being knows everything and a being that knows everything knows what time it is. Similarly, Wierenga (2021) conceives omniscience as the quality of having complete or maximal knowledge. It also means that God's knowledge is infallible and cannot be mistaken. If God's knowledge cannot be mistaken, then God is justified in his belief. This is why omniscience involves justification and belief. For instance, God knows that Blessed Orji is married and God believes that Blessed Orji is married. To believe otherwise is to be incongruous; for one cannot say I know that Blessed Orji is married but I don't believe that Blessed Orji is married. This is why knowledge is known as justified true belief.

There are various controversies associated with omniscience. One of them is whether or not omniscience is compatible with human freewill. Another is whether the notion of omniscience is compatible with the idea of immutability. The third one is whether or not omniscience is consistent with contingency. There is also the contention as to whether this knowledge is discursive, dispositional or occurrent. Knowledge of a proposition is dispositional if the person knows the proposition but it is not currently thinking about it or entertaining it while on the other hand a proposition is occurrentif the knower has such knowledge in mind (Wierenga (2021). To Aquinas, God's knowledge is not discursive because God does not arrive at a conclusion from premises. His knowledge is not in relation to other knowledge. It is in himself. Zagzebski (2008) even introduced the problem of omni subjectivity according to which God consciously grasps with perfect accuracy and completeness the first - person perspective. Therefore, omniscience in her view is more than knowledge of propositions. According to St Augustine, omniscience or foreknowledge is compatible with human freewill. In the dialogue between him and Evodius in the 'De Libero Arbitrio'Evodius expresses worry as to how God would foreknow that a man would sin and yet when he sins, he sins by volition and not by necessity. But Augustine elates his worries by maintaining that knowledge does not imply causality, for we foreknow the actions of men and such knowledge does not impose any necessity on them (On Free Choice of the will translated by J.J. Smith, 1948). Augustine further maintains that this foreknowledge is comprehensive; for he said, 'Anthony Kenny supports St Augustine's view that what God foreknows must necessarily happen because what God knows must be true: and indeed, what anyone knows must be true, since one cannot know what is false (Anthony Kenny, 1974).

But St Thomas Aquinas denies the idea of divine foreknowledge but rather proposes timeless knowledge. He opined that God cannot know the future which is not already determined by causal necessity. He held strongly that whatever God knows must be; for whatever is known by us must be and God's knowledge is more certain than ours. For if there is chicken republic in Port Harcourt of Rivers State, then there is Chicken Republic in Port Harcourt of Rivers State. But no future or contingent thing must be. Therefore, nothing which is future and contingent must be (Summa Theologiae, 1a, 14,3,3). In Aquinas' view there is no sequence or succession in God's knowledge. That is, there is no such thing as before or after in God's knowledge but he sees all things in one perfect and immutable manner. In other words, he comprehends everything in one single present. When Aquinas uses the word 'contingent' he refers to events which are not causally determined like the free acts of agents.

In the view of Aquinas, if God knew that this thing would be, then it would be, for the knowledge of God is of true things. He further argues that the antecedent of this conditioned proposition is absolutely necessary, because it is eternal, and because it is signified as the past. Therefore, the consequent is also absolutely necessary. It follows therefore, that what God knows is necessary; and so, the knowledge of God is not of contingent things (Aquinas, Summa Theologiae, part 1 trans. by Dominican fathers of English Province, 1947). Aquinas strengthens his argument with the illustration of a man who goes along on a particular road. The man cannot see those who come behind him. But let the man sit on a height 
above the road, he would be able to see all who go along the road in one moment. In the same way, he argues, that God sits on an Olympian height and observes all that happen or that would happen as if they were happening now. So, God has timeless knowledge instead of Foreknowledge, Aquinas argues. He sees everything in the eternal now. St Augustine held the notion of divine foreknowledge tenaciously but uses it interchangeably with timeless knowledge. He said,'There is nothing future, earlier or later with God; for in him there is nothing past, present or future (The City of God). Further, Augustine contends that this foreknowledge is exhaustive and comprehensive contrary to the view of open theism. By comprehensive knowledge, we mean that God knows with certaintythat which isitself uncertain. St Augustine said, 'No one knows what he himself is made of, except his own spirit within him, yet there is still some part of him which remains hidden even from his own spirit; but you, Lord, know everything about a human being, because you have made him...' (St Augustine, the confessions).Also, a person may change his mind at any time but providence knows that he would truly change it.

Jonathan Edwards agrees with the view that God has a certain and infallible pre knowledge of the free acts of agents and that these events which are foreknown by God are necessary with a necessity of connection or consequence. There are two aspects of the position of Jonathan Edwards. First is that any being known as God possesses infallible and certain pre knowledge of what creatures would do. The second aspect is the idea that these things foreknown by God are necessary by connection or consequence. The first position has been rejected by the open theists as we shall see in this study. The second aspect introduces some controversies particularly that of knowledge of contingency which some philosophers including the open theists had rejected vehemently. For the open theists, God cannot know contingent future and such a future is not necessary. That is, no future event can be known with certainty whose existence is contingent; for a thing cannot be known to the intellect without evidence (Edwards, 1974). But Edwards argues his point logically. He said whatever we as human beings know, must necessarily be even though such knowledge does not impose any necessity on the thing foreknown.

But on the periphery, the openness of God creates the impression that God is not the highest possible being because of its conception of a God who is limited in knowledge. Ironicallyopen theists deny this assertion. They agree that God is the highest possible being. But they think that infallible knowledge of future free acts is simply not possible. Again, does open theology not deny the predictions and prophecies in the Bible? 'Not so', the open theists maintain. The prophecies in the Bible are sometimes primarily moral discernments and moral judgment. And predictions are also what God has already decided to do and not what free creatures would do. For instance, God can predict the second coming of Christ because He is the one who fixed the time. What about prediction by Christ that Judas would deny him? Is it not an individual prediction? To this, the open theists argue that Jesus saw from the character of Judas that he would betray him. Open theism certainly begs many questions. First, some wonder how God can be in control of the world if He does not know the future in complete detail. For example, if by next week, Boko Haram would bomb the whole of the north east, Nigeria and Godare not aware of it, how would he control it? Does it not portray the idea that God is not in control? The open theists affirm that God is almighty and an almighty God can intervene in the course of events whenever he wants to (Layman, 2015). In the view of the open theists, the terrorists might be surprised that their bombs ceased working as a result of divine intervention. Second, is open theism not denying that God is omniscient? Their response to this poser is that it depends on the type of omniscience one is talking about. If it is the traditional understanding that God knows every truth and believes no falsehood, the truth-Value open theists agree to this. But God does not know truths corresponding to future free acts. Thus, they deny that God is omniscient in the traditional sense, but they offer a different definition of omniscience.

There is a significant difference between sovereignty models and open theism. The difference is that proponents of the open view are justified in claiming that petitionary prayer initiates unilateral divine activity that would not have occurred if we had not utilized our God given power of choice to request such divine assistance. This implies that God's plan is open to the extent that our free decisions bring their manifestation. God does not necessarily ensure that we freely make a given decision, for that would limit our freedom not to make that decision. There is another dimension of the openness theology. As Basinger observes, we maintain...that God possesses only what we call 'present knowledge' (Basinger 2003). In other words, God knows 'all that has occurred in the past and is occurring now.' Moreover, God does Know all that will follow deterministically from what has occurred, and can, as the ultimate psychoanalyst, predict with great accuracy what we as humans will freely choose to do in various contexts. It follows that God can predict an event with accuracy, but according to the open model, 'God can know only what can be known and that what humans will freely do in the future cannot be known before-hand; hence, God can never know infallibly, what will happen in any context involving human freedom (Basinger, 2003).

The openness view of God implies that the agent's long-term future is essentially unwritten, undetermined and open. This open view of God is shared to a large extent by some Latter-Day Saints. Although, the nature of God's knowledge is variously conceived among Latter Day saints, there is some degree of similarity in these conceptions. Some have thought that God increases endlessly in knowledge as well as in glory and dominion. But others have denied such belief. Most agree with Joseph Smith that God is eternally self-surpassing in knowledge and power. But some agree with President Woodruff that God himself is increasing and progressing in knowledge, power and dominion and would continue till the end of time.

\section{Gregory Boyd's Open Theistic Arguments}

Gregory Boyd uses scientific, philosophical and scriptural arguments in enunciating the open model. His scientific arguments are derived from quantum theory which conveys the notion of indeterminism. Quantum theory was a challenge to classical mechanics. Classical mechanics held that the universe is determined from the beginning of times such that given the same past one could expect a particular future. By this, it is possible to predict the outcome of events with 
precision. Classical physics gives no room for probability. But quantum mechanics is a probabilistic theory and the core of its position is that the outcome of future events is undetermined. So, Boyd pitches his tent with quantum theorists and argues that since there is indeterminism in the universe, the implication is that the future is open and can take any direction. And if the future can go any direction, there was no way such a future could be known by God (Boyd\& Boyd, 1994).

From a philosophical viewpoint, Boyd argues that the reason he opposes the classical notion of divine foreknowledge is because the future has no ontological existence until agents decide to bring them into being. He said:

To assume God knows ahead of time how every person is going to freely act is to assume that each person's free activity is there to know - even before he freely does it! But it's not. If we have been given freedom, we create the reality of our decisions by making them. And until we make them, they don't exist. Thus, in my view, at least, there simply isn't anything to know until we make it there to know (Boyd et al, 1994).

From the above arguments, we see that Boyd attributes some kind of knowledge to God. But what is this kind of knowledge? He claims that God knows whatever is there to know. That is, God knows the past and the present. The moment agents bring their choices to bear, then God knows it. He also claimed that God knows the present actions of men. This is the idea of 'until we make them, they don't exist.' But there is another type of knowledge Boyd claims that God possesses and this is the one that derives from knowledge of the character the individual has developed over time. Based on this, God is able to know what the individual is likely going to do. Hence, Boyd argues, God is not taken by surprise from what agents do. He illustrates his conviction with a 'Choose your own Adventure' children book. In this book, the author determines the entire outlay of the story together with the story lines, the directions and possibly, the end. But he allows the readers to take decisions on their own and these decisions determine the next outcome. As the Architect of the story who predetermines certain aspects and knows all the possibilities and probabilities, God can be relied upon to achieve his ultimate goal of creation (Boydet al 1994).

In addition to the philosophical viewpoint, Boyd makes allusion to scriptural texts which convey the idea that the future is partly settled and partly open. He calls them the 'motif of determinism'and the 'motif of openness.' The first refers to Biblical texts which portray the notion of determinism while the later points to texts that exemplify openness. The main import of the motif of determinism is that God has foreknowledge of certain future events and sometimes overrides man's freedom to accomplish his objective. He refers to certain predictions in the Bible such as the going into slavery by the Israelites as an indication of determinism.On the design on openness, he refers to conditional statements such as the one made by Christ in Gethsemane to support his argument. During the agony at Gethsemane, Christ said prayers that caught the attention of Boyd. He said: 'God, if it is possible let this cup pass over me. Nevertheless, not as I will but as you will.'There is no gainsaying the fact that the words carry the impression of uncertain knowledge. 'If' statement in our language parlanceis conditional and it refers to something that may or may not be.

Gregory Boyd claims that God is omniscient because he knows everything that there is to know, in addition to perfectly knowing the past and the present, and he also knows all the possibilities of what free creatures may do in the future (Boyd 2001). He further maintains that, based on God's perfect knowledge of the nature of human beings, God knows what people are most likely going to do in any given situation based on the consistent character they have developed by decisions they have made throughout their lives. According to Boyd, God possesses perfect knowledge and infinite intelligence and is thus, never taken unawares by what creatures freely choose to do (Boyd 2001). He further opines that the Bible has two categories of passages or motifs that are very essential in our understanding of God's relationship to the future. He labels them as the 'motif of determinism' and the 'motif of openness.' His view of the scriptural passages on the motif of determinism is that there are passages that portray God as having foreknowledge of future events. This includes passages that narrate God's knowledge of a variety of future occurrences, including circumstances that would befall Israel, events in the ministry of Christ, particular choices that would be made by specific individuals and the consummation of God's eschatological plans (Boyd 2001).

On the other hand, Boyd makes reference to Biblical texts that convey the notion of openness or the motif of openness. These passages, according to him, appear to describe a God who regrets the actions of humans and even the results of the decision that He Himself has made, who is surprised by unexpected events, who tests people to see what they would do, who speaks in terms of what may or may not occur and who changes His mind about certain things and reverses His intentions (Boyd 2001). Also, God would not make conditional statements if he knew what the actions of men would be. Boyd cites a number Scriptural texts to buttress his arguments. In the Book Exodus 4:1-9, God spoke as if He did not know exactly what would be the reaction of the children of Israel when Moses goes to them with the message of God. It would be proper to cite the text for purpose of clarity. The text reads:

Then the Lord said, 'Put your hand inside your cloak.'So, Moses put his hand into his cloak, and when he took it out the skin was leprous - it had become as white as snow. 'Now put it back into your cloak,' he said. So, Moses put his hand into his cloak, and when he took it out, it was restored, like the rest of his flesh. Then the Lord said, 'If they do not believe you or pay attention to the first sign, they may believe the second. But if they do not believe these two signs or listen to you, take some water from the Nile and pour it on the dry ground. The water you take from the river will become blood on the ground' (Exodus 4:6-9, NIV).

From the above passage, as Boyd remarks, God does not seem to know exactly what the reactions of the children of Israel would be. If He was sure of their reactions, He would have given to Moses at the very beginning, the approach that would evoke the expected reaction. Boyd also clarifies his position from the use of the word, if they do not believe you or pay attention to the first sign, they may believe the second.' On this basis, Body argues that if God knew the future perfectly, He would not make conditional statements as the one in the above text. 
says:

And it came to pass, when Pharoah had let the people go, that God let them not through the way of the land of the philistines, although that was near; for God said, lest peradventure the people repent when they see war, and they return to Egypt.

Again, the text clearly paints the picture of a God who is uncertain of the reaction of the people, humanly speaking. According the text, God felt (and feeling is different from knowledge) that if the children of Israel upon leaving the land of Egypt took the way of the philistines and the philistines attack them, they may (peradventure) change their mind and return to Egypt. The concern of Boyd is that an Omniscient knower in the classical sense should not speak like this. He should speak with precision having known all the possibilities to an action.

Boyd, therefore, concludes that the future is partly settled and partly open. Following Boyd's line of reasoning, Layman (2015) argues that God's knowledge of the future is infallible whenever it is grounded in divine decree. That is, God possesses knowledge of what he intends to do or what he has decided to do. Further, to say that God's knowledge of future free acts is fallible does not mean that God has false beliefs. And that while many theologians shrug at the notion that any of God's knowledge is fallible, he maintains that infallible knowledge of future free acts is simply not possible (Layman 2015). But he remarks that this is not a defect in God.

Having identified scriptural texts that have the idea of limited and in exhaustive knowledge Boyd is now faced with the challenge of providing explanations for accurate predictions in the Bible. Let us examine a few of them. In II Kings 23:1516, it is said:

Moreover, the altar that was at Bethel, and the high place which Jeroboam the son of Nebat, who made Israel to sin, had made, both that altar and the high place, he broke down and burned the high place, and stamped it small like powder, and burned the grove. And as Josiah turned himself, he spied the sepulchers that were there in the mount, and sent and took the bones out of the altar, and polluted it, according to the word of the Lord which the man of God proclaimed, who proclaimed these words (KJV).

It is important to recall that what happened in this text took place in 1 Kings 13. We may refer to it for the purpose of clarity and to remove any iota of doubt. Here is what it says:

By the word of God, a man of God came from Judah to Bethel, as Jeroboam was standing by the altar to make an offering, by the word of the Lord he cried out against the altar: 'Altar, altar! This is what the Lord says: 'A son named Josiah will be born to the house of David. On you he will sacrifice the priests of the high places who make offerings here, and human bones will be burned on you' (I Kings 13:1-3, NIV)

The above text is undeniably a portrayal of God who can make accurate predictions. As the passage mentions, the man of God went to Bethel from Judah and got to the house of the gods and saw king Jeroboam offering sacrifices on the altar. The man of God quickly prophesied against the altar and said the prophecy would come to fulfillment in the time of Josiah. According to his word, Josiah later became king of Judah and began his reforms in the land. The result of it was the burning of the sepulchers of the priests of the altar as predicted by the man of God. This is a clear indication of an event that is fixed from a remote past for which nothing can be done to avert it. It is also an indicationof divine foreknowledge; for it came to be as was prophesied.Boyd does not deny this assertion and immediately opines that it is one of the scriptures on the motif of determinism.

Boyd further argues that his open theistic view has more practical implications than the classical notion. According to him everyday people evaluate numerous options before them. They make decisions on what type of school to send their children. They decide the type of job to do and the state to go to on holiday. They make a choice of the kind of food they want to eat and so on (Boyd, 2001). They do this in a way that implies that their thinking is that the future is open and they have some degree of control over it. Most times they do act as if they were designed to make such decisions. This is why they engage in social welfare because they believe that their action counts. Some are crusaders against injustice because they believe that their action would go a long way to reduce the injustices in the society. In other words, they do not see events happening around them especially those caused by agency to be iron clad on the stone. Also, open theism makes sense when we engage in petitionary prayer. When we pray, it is because we think that our prayer can influence God in our favour. If we think that the future is completely settled as Boyd argues, then prayer makes no sense. Further, Boyd argues that open theism makes intellectual sense more than classical theism and it is a reflection of the daily actions and reactions of people.

Boyd further insists that if God were omniscient in the classical sense, he would not ask certain questions. Recall that in some parts of the Biblical account, God is seen asking questions such as the one he posed to Adam and Eve after they had eaten the forbidden fruit. God Asked Adam, 'Where are you?', 'How did you know that you were naked?' and 'Have you eaten the fruit of the tree I forbade you to eat?'similarly, when the sons of God presented themselves to God, Satan also came and God asked him, 'Where are you coming from?' and'Haveyou considered my servant Job?'Boyd contends that it would be insincere on the part of God to ask questions that he already knows the answers. This, according to him, is tantamount to pretending to know less and this is disingenuous. So now, can God be said to be disingenuous?

The opponents of the open model have argued against the literal interpretation of the Scriptures quoted by Boyd insisting that they are anthropomorphisms in Biblical texts. They are texts where God accommodates himself and communicates with man so that he would achieve success in understanding or in the cognitive realm. But Boyd rejects that position and argues that the openness passages do not seem to be anthropomorphic and that those who want to sue for anthropomorphism to explain them are doing so because they are uncomfortable with the implications of a literal reading of the texts. He also contends that to claim anthropomorphism is to take the integrity of scripture for granted; for how else would one explain the statement that God became frustrated, if not that he did not know exactly what the 
outcome would be. So, for Boyd, when the scripture said God changed his mind, it means what it says and connotes that he did not know long ago with precision what the outcome would be (Boyd 2000)

\section{A Critical Analysis of Gregory Boyd's Open Theistic Arguments}

In this section we shall critically evaluate Gregory Boyd's views in support of the open model. In the first place, Boyd maintains that the future is partly open and partly settled. The settled part of the future which are supported by Scripture, he called the motif of determinism and the unsettled part he called motif of openness. According to him, God predestines some aspects of history in order to achieve his aim. By implication, God predetermines what he foreknows and that predetermination goes a long way to influence the actions and choices of individuals. But it is surprising that Boyd, an open theist, is maintaining such a stance which runs counter to the open model. Generally, determination is not compatible with the open view (Grossl et al 2014) because open theists tenaciously hold that humans are free. The question is, in those areas with a settled future, does any man have freedom? There is no doubt that the motif of determinism violates the freedom of action and hence contradicts the open view. This is why CorinMihaila (2002) has argued that it is baseless to anchor the tenets of the open view on freedom when, according to the open theists, God can remove that freedom to achieve his purpose. Rather than hold that God violates or overrides the freedom of agents sometimes to accomplish his purpose, it would have been proper to maintain that God contributes an indeterminate element in his relationship with man to achieve his ultimate purpose without violating the freedom of man. This would be in tandem with a significant part of Boyd's open theistic theological construct. What do we mean?In the relationship between God and man, God can decide to act like the rug maker who as he works with his children allows his children to do their part at their own end. But he adjusts the work at his own end without interfering with his children's freedom. Yet he achieves his ultimate goal. What God contributes can be called an INDETERMINATE ELEMENT. It is also indeterminate because it depends on what the individual does with his freedom. It is not any particular thing. We may call this the INDETERMINATE FACTOR THEORY OF PROVIDENCE in which case God foreknows the action of agents, yet does not interfere with their freedom because he contributes an indeterminate element which accomplishes his goal. We can illustrate this further with the case of a paste maker. Let us assume that to make a paste we require sugar and flour. The producer and his workers are set to produce a certain quantity of paste. The workers are to supply the sugar while the producer supplies the flour. Let us further assume that the quality of sugar needed is $0.3 \mathrm{~kg}$ and this would be combined with $0.5 \mathrm{~kg}$ of flour to produce the desired paste. Let us assume further that instead of bring $0.3 \mathrm{~kg}$ of sugar the workers of their volition bring in $0.33 \mathrm{~kg}$ of sugar. The producer on noticing this does not interrupt them. Rather he increases the quantity of flour to be used and still achieves the desired quality of paste. In the same way God uses this indeterminate element to achieve a desirable state of affairs without violating the freedom agent.

Boyd also contends that the notion of foreknowledge presupposed that God is the cause of the action of the agent. This is a traditional argument which St Augustine gave a prominent place in scholarship. The argument is that if God foreknows a thing, then it must necessarily happen. And if it must necessarily happen, then the individual is not free to choose or act otherwise. If the individual is not free to choose or act otherwise, it then means that God is the cause of the individual's action. But St Augustine denies the conclusion and maintains that knowledge does not imply causality. This view was re - echoed by some scholars who opine that everything that God knows about the future, he knows only because it will happen and vice versa.

There is a problem with the open theistic response. The case of Jeremiah who God said he knew from his mother's womb is a glaring example contradicts the open view.Obviously, there was nothing in the character of Jeremiah to help God know him with precision because he had not yet been born. We can stretch the argument further. If prophecies are primarily the products of people's character, what about prophecies on the nation when of course, there is not one kind of behavior in the nation. In Genesis 13, God told Abraham that his seed would go into bondage and would be maltreated by the oppressive, cruel and barbaric nation. That prophecy as the Biblical narrative shows, came to be fulfilled. On this note we think that the open model breaks down.

Generally, the open view claims it has more practical relevance than the other sovereignty models. In the view of Clark Pinnock (2003), the open view of God stresses qualities of generosity, sensitivity and vulnerability more than that of power, dominance and control. In other words, the open view sees God as omnipotent and yet he allows his love to rule his power. This seems contrary to the notion of immutability, a basic tenet of classical theism. By this God gives the individual a certain degree of freedom and this, sometimes, gives rise to an unsettled future. In the same way Basinger (2014) claims that it is because the future is open that we approach God in prayers andoffer our Christian explanation to the problem of evil. That is, we pray because we believe that our prayer can change God. The changing of the mind of God becomes an eloquent testimony of the openness of the future. Again, the notion that evil exists in the presence of an all knowing, all powerful and all good God finds plausible explanation in the open view. In the open view, the presence of evil in the world is not inconsistent with the notion of God but with the notion of God in classical theism.

\section{Conclusion}

Open theism came to be known as an alternative to divine Sovereignty thesis. It claimed to be a more appropriate interpretation with better practical application to the relationship between God and man. This is because, in their view, the future is partly open and partly settled unlike classical theism. It claimed to be a better response and explanation to the problem of evil. It also contends that it provides a better understanding of the Christian response to social problems, the import of intercessory prayers and engagement in evangelistic activities. Gregory Boyd was one of the major proponents of open theism. But as we have said, Gregory Boyd contradicts himself in several respects. His acceptance that there are scriptures on determinism together with texts that deal with freedom contradicts the open view that human beings are 
free. Also, his notion that God sometimes overrides the will of manto accomplish his desires falls into the same mesh as the former. This is a great challenge to the open view which is built solely on the freedom of man. The open view, though with its own challenges, does have some merits. Its emphasis on human freewilledserves commendation. This is because from a practical point of view, humans are free. When we arraign people in court for certain offences, it is because we felt they could have done otherwise. When we punish our children for certain misbaviours, it is because we believed they could have done otherwise. When we praise people for good work, it is because, we thought, they could have done what was blameworthy. On this we give credit to Gregory Boyd and his open view. But we reject his notion that God does not know the future because it is open. It is the position of this study that the future may be open but God knows in what direction it would go. It is our view that an individual may change his mind, but God knows that he would change it; for God has supper intelligence and infinite forecasting powers. We contend that certain aspects of the Biblical texts which seem to convey the notion of a God who is limited in knowledge may be those areas where God accommodates himself and condescends to the level of man in order to communicate with man. There is no doubt that there is epistemic distance between man and God. So, the human intellect may not be able to comprehend all that is divine.

\section{References}

i. Anthony, K. (1974). Divine foreknowledge and human freedom. In Brody, B.A. (Ed.). Readings in the philosophy of religion: An analytic approach. New Jersey: Prentice- Hall.

ii. Basinger, D. (2003). Practical implications. In Pinnock, P., Rice, R., Sanders, J., Basinger, D. The openness of God: $A$ Biblical challenge to the traditional understanding of God.

iii. Basinger, D. (2014). Middle knowledge and classical Christian thought. In Michael, P., William, H., Reinchenbach, B., David, B. (Eds.). Philosophy of religion: Selected readings. New York: Oxford University Press.

iv. Boyd, G. (2000). God of the Possible: A biblical introduction to the open View of God. Baker Books: Grand Rapids, MI

v. Boyd, G. (2001). The open theism view. In James K. Beilby, Paul, R.E. (eds). Divine foreknowledge: Four views. InterVasity Press: Downers Grove, ILL.

vi. Boyd, G., Boyd, E. (1994). Letters from the skeptic. Victor Books: Wheaton, IL

vii. Edwards, J. (1974). Foreknowledge inconsistent with contingency: In Baruch A. Brody Philosophy of religion. New Jersey: Prentice Hall.

viii. Grossl, J., Vicens, L. (2014). Closing the door on limited - risk open theism. Faith and philosophy31, no 4, 476.

ix. Layman, C.S. (2015). Divine Foreknowledge and human freewill: Four views. https.academics.edu

x. Mihaila, C. (2002). The Ignorant God of Open Theism. Faith and Mission 19, no 3, 27-29.

xi. Normam, K. (1974). Omniscience and Immutability. In Baruch A. Brody (ed.). Readings in the Philosophy of Religion: An Analytic Approach. New Jersey: Prentice Hall.

xii. Pinnock C. (2003). Systematic theology. In Pinnock, P., Rice, R., Sanders, J., Basinger, D. The openness of God: $A$ biblical challenge to the traditional understanding of God.

xiii. Smith, J.J. (trans.) (1948). Augustine: The city of God, BK V Ch. X; Basic Writings of St. Augustine, Vol. II: New York.

xiv. Steve, B. (2003). Omniscience. In Chad, B., Charles, D., Steve, B., Ray, C. Trent, C.B., Bill, L. (2003). Holman Illustrated Bible Dictionary. China: Holman Publishers.

xv. Vanarragon, R.J. (2010). Key terms in philosophy of religion. New York: Continuity international publishing group.

xvi. Wierenga, E. (2021). Omniscience. Stanford Encyclopedia of Philosophy. Plato.stanford. edu.

xvii. Zagzebski, L. (2008). Omni-subjectivity in Jonathan Kvanvig (ed). Oxford Studies in Philosophy of Religion. Oxford: Oxford University Press. 